Article

\title{
Micro-Raman Spectroscopy Investigation of Crystalline Phases in EAF Slag
}

\author{
Alessandro Riboldi ${ }^{1}$, Laura Borgese ${ }^{1}$, Irene Vassalini ${ }^{1}$ (i), Giovanna Cornacchia ${ }^{2}$, \\ Marcello Gelfi ${ }^{2}$, Marco Virginio Boniardi ${ }^{3} \mathbb{D}$, Andrea Casaroli ${ }^{3}$ and Laura Eleonora Depero ${ }^{1, *}$ \\ 1 Chemistry for Technologies Laboratory, INSTM and Department of Mechanical and Industrial Engineering, \\ University of Brescia, Via Branze 38, 25123 Brescia, Italy; alessandro.riboldi@unibs.it (A.R.); \\ laura.borgese@unibs.it (L.B.); irene.vassalini@unibs.it (I.V.) \\ 2 Metallurgy at Department of Mechanical and Industrial Engineering, University of Brescia, University of \\ Brescia, Via Branze 38, 25123 Brescia, Italy; giovanna.cornacchia@unibs.it (G.C.); \\ marcello.gelfi@unibs.it (M.G.) \\ 3 Department of Mechanical Engineering, Polytechnic University of Milan, Via La Masa 1, 20156 Milan, Italy; \\ marco.boniardi@polimi.it (M.V.B.); andrea.casaroli@polimi.it (A.C.) \\ * Correspondence: laura.depero@unibs.it
}

Received: 27 April 2020; Accepted: 11 June 2020; Published: 15 June 2020

check for updates

\begin{abstract}
Electric arc furnace (EAF) slags were investigated by micro-Raman spectroscopy. A slag sample characterised by well-developed crystalline phases was obtained. The EDXS elemental composition made it possible to recognize the grains corresponding to the brownmillerite, larnite and magnesioferrite phases, as identified by XRD in the same powdered sample. The grains were collected and analysed by $\mu$-Raman spectra, and the results showed good reproducibility in each grain and good agreement with spectra of the phases reported in the literature. A Raman database devoted to crystalline phases of EAF slag identification was created to be used by portable Raman instruments, allowing the phase characterisation of the slag directly during steel production.
\end{abstract}

Keywords: EAF slag; micro-Raman investigation; XRD characterisation; SEM-EDX characterisation; spectra database; crystalline phases

\section{Introduction}

Steel production is one of the most widespread industrial activities in the world. The overall annual production of crude steel in 2017 was estimated at about $1690 \mathrm{Mt}$ by the Worldsteel Association. The major producers are China, Japan and India, with about 832, 105 and 101 Mt, respectively, in 2017. In Europe, Italy plays a vital role, with a production of $24 \mathrm{Mt} /$ year, being the second largest producer after Germany [1].

In Electric Arc Furnace (EAF), slags are formed on a steel bath for the effect of lime and injected oxygen. The slags are about $10-15 \%$ in weight of steel production [1,2]. EAF slags are classified as black and white slags. Black slag has a lime content less than $40 \%$, and results from the cold loading of scrap. White slag has a lime content higher than $40 \%$ and is generated during grinding when lime is added to remove sulphur and phosphorus.

Black slags vary with the steel produced (EAF-C from carbon steel production and EAF-S from the production of stainless steel/high alloyed steel), and the chemical composition depends on the scraps, the quantity of oxygen adopted during the melting process and furnaces process [3]. Both slags are mainly formed of oxides $\mathrm{FeO}, \mathrm{CaO}, \mathrm{SiO}_{2}, \mathrm{Al}_{2} \mathrm{O}_{3}, \mathrm{MgO}$ and other impurities in a wide range of percentages $(10-40 \%, 22-60 \%, 6-34 \%, 3-14 \%$, and $13-14 \%$, respectively). Ca and $\mathrm{Si}$ come from the materials added to the liquid steel bath, while $\mathrm{Mg}$ originates from the attack of steel bath to the furnace firebrick. Other elements, such as $\mathrm{Cr}, \mathrm{Ti}, \mathrm{Cu}$, are impurities present in the ferrous scrap [3,4]. 
Crystals formation in slag is strongly affected by both the chemical composition of the molten slag and the cooling rate, which usually depend on the protocols of each steel plant. Significant variation of the slags is also due to the kind of steel produced [3]. For this reason, the identification of the crystalline phases is crucial, and is usually carried out by external laboratories. Thus, a technique that permits fast characterisation of the slag by unskilled personnel would be very beneficial for the quality control of steel production.

In the scientific literature, the effects of the slagging procedures on the mineralogical and morphological structure of EAF slag have already been discussed. For example, the addition of $\mathrm{SiO}_{2}$ combined with rapid cooling favours the formation of glassy phases [3]. The main crystalline phases, usually identified by $\mathrm{XRD}$, are larnite $\left(2 \mathrm{CaOSiO}_{2}\right)$, brownmillerite $\left(\mathrm{Ca}_{2}(\mathrm{Al}, \mathrm{Fe})_{2} \mathrm{O}_{5}\right)$, wustite $(\mathrm{FeO})$, calcium silicate, silicon aluminates, gehlenite $\left(\mathrm{Ca}_{2} \mathrm{Al}\left(\mathrm{AlSiO}_{7}\right)\right)$, bredigite $\left(\mathrm{Ca}_{7} \mathrm{Mg}\left(\mathrm{SiO}_{4}\right)_{4}\right)$, magnetite $\left(\mathrm{Fe}_{3} \mathrm{O}_{4}\right)$, and magnesioferrite $\left(\mathrm{MgFe}_{2} \mathrm{O}_{4}\right)[5,6]$.

The main techniques adopted for investigating the structural and chemical composition of slags are: Powder X-ray Diffraction (PXRD) for the crystalline phase identification and Scanning Electron Microscopy (SEM) coupled to Energy Dispersive X-ray Spectrometry (EDXS) for the morphological and elemental analysis of the phases [7]. PXRD needs the samples to be pulverised and homogenised; thus, the patterns contain the signals of altogether the crystalline phases, making their identification sometimes tricky. Moreover, PXRD analysis does not give any information about the amorphous phases present in the sample.

Raman spectroscopy is used in many applications, such as medicine, chemistry and remote sensing for the structural and chemical analysis [8]. Spectroscopic techniques are based on the interaction between electromagnetic radiation and matter and are based on the phenomenon of emission, absorption, fluorescence or scattering. Raman spectroscopy typically uses laser light in the visible field, near-infrared or near-ultraviolet fields to excite the vibro-rotational energy levels of molecules by generating scattered light [9]. The incident photons will interact with the system, and the amount of energy change by a photon is characteristic of the nature of each bond present. Not all vibrations will be observable with Raman spectroscopy, but sufficient information can usually be identified to enable the characterisation of the phases of the sample [10].

Raman spectroscopy is a powerful technique that has many advantages over other common analytical techniques. It offers very detailed sample characterisation by probing individual chemical bond vibrations. As a result, a Raman spectrum is information rich, and contains data relating to the specific chemical structure of the material being analysed. It can be used to fully characterise the sample composition, and a fast phase identification is possible with databases. Beyond general material identification and characterisation, Raman spectroscopy also probes more subtle chemical effects, such as crystallinity, polymorphism, phase, intrinsic stress/strain and hydrogen bonding. Raman spectroscopy is a very fast technique, typically requiring just a few seconds to obtain a good quality spectrum. It is a real non-destructive technique, since it is non-contact, non-destructive, and requires no sample preparation. For these reasons, it is suitable for true in situ analysis [11].

The recent advancement of technology in laser and spectrometer miniaturisation and the improved filters for laser light rejection and fibre-optic probes has allowed the development of portable Raman spectroscopy systems. There are other spectroscopic techniques complementary to Raman, such as Fourier transform infrared (FT-IR) and near-infrared (NIR) spectroscopy. However, because of the high sampling rate and spectral specificity, it is an invaluable tool for understanding the impact of process changes on the process and product.

Some examples in the scientific literature have already demonstrated the advantages of the characterisation of EAF slag by using Raman spectroscopy [8].

The aim of this work is the evaluation of Raman spectroscopy in the characterisation of EAF slag to demonstrate the possible use of Raman spectroscopy for fast and reliable phase identification and quality control. Among the various types of Raman spectroscopy, micro-Raman techniques make it possible to perform the analysis of areas of a few square microns, while portable Raman usually has 
a spot of some millimetres. As a consequence, the spectra obtained by portable Raman are usually the sum of the contribution of several phases. As a preliminary work, we perform the micro Raman analysis of a well-crystallised EAF slag sample to properly collect the spectrum of each phase.

\section{Materials and Methods}

\subsection{Samples}

Black slags were collected from EAF steel plants located in the province of Brescia. Most of the studied slags came from carbon-steel production, except for sample A, which came from the production of special steel. Information about the carbon content of produced steel, melting temperature of furnace and slag samples treatment after slagging, such as cooling practice and use of additivities, are presented in Table 1. The samples were characterised by different techniques (see Table 2). For the identification of the phases, the size of homogeneous domains in the sample is crucial. For this reason, a preliminary Raman analysis was performed on a sample characterised by well-developed crystalline phases (sample A in Table 1), a low alloyed steel nominally containing 2.25\% chromium [12].

For SEM-EDXS, Raman spectroscopy and XRD analyses, sample A was prepared according to the standard metallographic polishing procedure [13]. For XRD on powder analysis, samples B, C, D and E were pulverised and sifted into particle sizes below $106 \mu \mathrm{m}$ using an ASTM E11-70 certified sieve.

Table 1. Description of samples, details of some steel making process parameters (2nd and 3rd column) and slagging procedure (4th column).

\begin{tabular}{|c|c|c|c|}
\hline Sample & Steel Type & Furnace Temperature $\left[{ }^{\circ} \mathrm{C}\right]$ & Slagging Procedure \\
\hline A & Special Steel & n.d. & \multirow{5}{*}{$\begin{array}{l}\text { n.d. } \\
\text { on chute and cooled by water } \\
\text { on chute and cooled by water } \\
\text { on chute and cooled by water } \\
\text { after } \mathrm{SiO} 2 \text { treatment } \\
\text { on chute and cooled by water }\end{array}$} \\
\hline $\mathrm{B}$ & Carbon steel $0.167 \%<\mathrm{C}<0.185 \%$ & $1550-1620$ & \\
\hline $\mathrm{C}$ & Carbon steel & 1600 & \\
\hline $\mathrm{D}$ & Carbon steel C $<0.25 \%$ & 1600 & \\
\hline $\mathrm{E}$ & Carbon steel: $0.05 \%<\mathrm{C}<0.8 \%$ & 1650 & \\
\hline
\end{tabular}

Table 2. Analytical techniques adopted on each sample.

\begin{tabular}{ccccc}
\hline & \multicolumn{5}{c}{ Techniques } \\
\cline { 2 - 5 } Sample & \multicolumn{2}{c}{ XRD } & Raman Spectroscopy & SEM-EDXS \\
\cline { 2 - 5 } & 2D XRD & Powder & \\
\hline A & $\sqrt{ }$ & $\times$ & $\sqrt{ }$ & $\sqrt{ }$ \\
B & $\times$ & $\sqrt{ }$ & $\sqrt{ }$ & $\sqrt{ }$ \\
C & $\times$ & $\sqrt{ }$ & $\sqrt{ }$ & $\sqrt{ }$ \\
D & $\times$ & $\sqrt{ }$ & $\sqrt{ }$ & $\sqrt{ }$ \\
E & $\times$ & $\sqrt{ }$ & $\sqrt{ }$ & \\
\hline
\end{tabular}

\subsection{SEM-EDX}

Morphological and compositional characterisation of a polished section of all samples were performed by LEO EVO 40 XVP scanning electron microscopy (SEM) in backscattering mode. The elemental semi-quantitative analysis was performed using an energy-dispersive $X$-ray spectroscopy (EDX, Cambridge, MA, USA) microprobe (Link Pentafet Oxford mod 7060). The analysis was performed in $\mu \mathrm{m}$ areas of selected grain.

\section{3. $X R D$}

The measures on sample B, C, D and E were performed using a Panalytical X'Pert Pro diffractometer equipped with an $X^{\prime}$ Celerator detector and $\mathrm{Cu}$ anode $(\mathrm{CuK} \alpha=0.15406 \mathrm{~nm})$, operating at $40 \mathrm{KV}$ and $40 \mathrm{~mA}$, and crystalline phases were identified. The patterns were collected in Bragg Brentano geometry 
between $5^{\circ}$ and $80^{\circ}$ (in $2 \Theta$ ). Qualitative analysis of the crystalline phases was performed by X Pert high score plus database. Sample A was analysed in three different areas by two-dimensional X-Ray Diffraction (2D-XRD). The analysis was obtained using Bruker D8 Discover instrumentation (copper anode, VANTEC-500 2D detector, voltage $40 \mathrm{~kW}$ and current $40 \mathrm{~mA}$, POLYCAP lenses, $1 \mathrm{~mm}$ beam size). The three investigated areas were similarly analysed using SEM and EDXS.

\subsection{Raman Spectroscopy}

The Raman characterisation of the metallographic section of each sample was carried out with a high-resolution Raman microspectrometer (Labram HR-800, Horiba Jobin-Yvon) using a He-Ne laser source $(\lambda=632.8 \mathrm{~nm})$. All the spectra were acquired in backscattering mode, using a $50 \times$ (Numerical Aperture: 0.5 ) microscope objective to focus and collect the exiting light. The analysis was performed on the same areas and grains analysed by SEM and EDXS. Each analysed point was measured three times in order to assess the sample stability under the laser beam.

\section{Results and Discussion}

\subsection{SEM-EDX}

Chemical and morphological analyses were performed on each sample. In Figure 1 the SEM micrographs of samples A are shown. The growth of the crystalline phases within steel waste is strongly affected by the cooling speed and the addition of additives during the deslagging step (for example $\mathrm{SiO}_{2}$ ) $[6,14,15]$. Due to the slow cooling rate, sample A is characterised by well-developed grains. Instead, sample $\mathrm{D}$ is characterised by white dendritic structures, due to the high cooling speed and the addition of silica during the deslagging. Samples B, C and E are characterised by grains of similar size, because of the similar cooling treatment (see Table 1). The grain colours range from white to dark grey. Each colour shade corresponds to different compositions, as discussed in our previous work [16]. EDXS results are reported in Table 3. Because of the large grains, sample A was chosen as a reference sample for the phase identification. SEM micrographs and EDXS results of samples B, C, D and $\mathrm{E}$ are reported in the Supplementary Materials.

Table 3. EDXS analysis of sample A (molar\%) in the points indicated in Figure 1 and the predicted crystalline phase.

\begin{tabular}{|c|c|c|c|c|c|c|c|c|c|c|c|c|c|c|c|c|}
\hline \multirow[t]{2}{*}{ Sample } & \multirow[t]{2}{*}{ Area } & \multirow[t]{2}{*}{ Position } & \multicolumn{13}{|c|}{ Atomic\% } & \multirow[t]{2}{*}{$\begin{array}{c}\text { Phase } \\
\text { Identification }\end{array}$} \\
\hline & & & O & $\mathrm{Mg}$ & Al & $\mathrm{Si}$ & $\mathrm{Cl}$ & $\mathrm{Ca}$ & $\mathrm{Ti}$ & V & $\mathrm{Cr}$ & Mn & $\mathrm{Fe}$ & Ba & $\mathbf{W}$ & \\
\hline \multirow{24}{*}{ A } & \multirow{6}{*}{1} & 1 & 51.4 & - & 12.6 & - & - & 25.0 & - & 0.9 & - & - & 10.1 & - & - & Brownmillerite \\
\hline & & 2 & 52.6 & - & 0.4 & 16.0 & - & 30.3 & - & 0.3 & - & - & 0.4 & - & - & Larnite \\
\hline & & 3 & 40.4 & 9.7 & - & - & - & 6.4 & - & - & 0.4 & 8.5 & 34.6 & - & - & Magnesioferrite \\
\hline & & 4 & - & - & - & - & - & - & - & - & - & - & 100.0 & - & - & Iron \\
\hline & & 5 & 50.6 & - & 13.0 & - & - & 24.4 & - & 1.0 & 1.2 & 0.4 & 9.4 & - & - & Brownmillerite \\
\hline & & 6 & 41.2 & - & 1.4 & - & 4.6 & 12.4 & - & 10.2 & - & - & 5.3 & 22.0 & 3.0 & $*$ \\
\hline & \multirow{10}{*}{2} & 1 & 50.8 & - & 8.5 & 3.6 & - & 25.4 & - & 0.6 & 5.5 & - & 5.6 & - & - & Brownmillerite \\
\hline & & 2 & 43.54 & 13.56 & - & - & - & 6.12 & - & - & 0.71 & 7.7 & 28.37 & - & - & Magnesioferrite \\
\hline & & 3 & 50.7 & - & 11.4 & - & - & 24.2 & - & 0.6 & 6.3 & - & 6.8 & - & - & Brownmillerite \\
\hline & & 4 & 42.0 & 12.1 & - & - & - & 4.56 & - & - & 0.58 & 8.84 & 31.95 & - & - & Magnesioferrite \\
\hline & & 5 & - & - & - & - & - & 0.7 & - & - & - & - & 99.3 & - & - & Iron \\
\hline & & 6 & 49.4 & - & 10.9 & 0.6 & - & 24.7 & 0.4 & 0.7 & 6.3 & - & 7.1 & - & - & Brownmillerite \\
\hline & & 7 & 40.8 & 12.6 & - & - & - & 3.1 & - & - & - & 10.1 & 33.4 & - & - & Magnesioferrite \\
\hline & & 8 & 40.5 & 14.7 & - & - & - & 2.5 & - & - & 0.4 & 10.4 & 31.4 & - & - & Magnesioferrite \\
\hline & & 9 & 51.4 & - & 9.9 & - & - & 23.9 & 0.4 & 0.6 & 6.0 & 0.6 & 7.3 & - & - & Brownmillerite \\
\hline & & 10 & 52.9 & - & - & 15.9 & - & 30.8 & - & - & - & - & 0.4 & - & - & Larnite \\
\hline & \multirow{8}{*}{3} & 1 & - & - & - & - & - & 0.87 & - & - & - & - & 99.1 & - & - & Iron \\
\hline & & 2 & - & - & - & 1.3 & - & - & - & - & - & - & 98.7 & - & - & Iron \\
\hline & & 3 & 52.7 & - & 10.5 & - & - & 23.1 & 0.4 & 0.6 & 6.0 & - & 6.8 & - & - & Brownmillerite \\
\hline & & 4 & 52.9 & - & 11.0 & - & - & 23.48 & - & 0.7 & 4.4 & - & 7.6 & - & - & Brownmillerite \\
\hline & & 5 & 42.9 & 14.1 & - & - & - & 3.54 & - & - & 1.4 & 8.4 & 29.7 & - & - & Magnesioferrite \\
\hline & & 6 & 47.1 & 11.1 & - & - & - & 8.57 & - & - & - & 6.5 & 26.8 & - & - & Magnesioferrite \\
\hline & & 7 & 52.8 & - & - & 16.0 & - & 30.29 & - & 0.4 & - & - & 0.6 & - & - & Larnite \\
\hline & & 8 & 54.2 & - & - & 15.6 & - & 30.21 & - & - & - & - & - & - & - & Larnite \\
\hline
\end{tabular}




\section{Sample A}

(1)

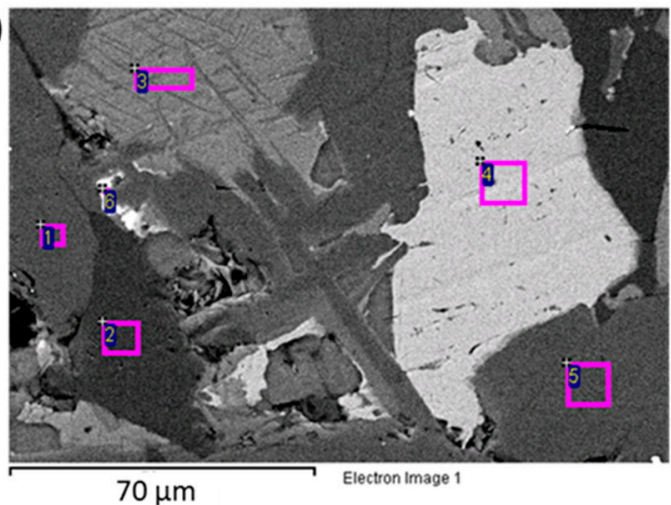

(2)

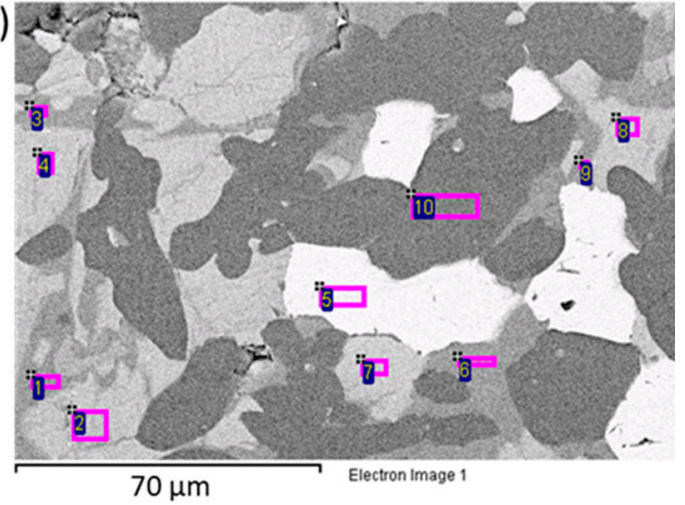

(3)

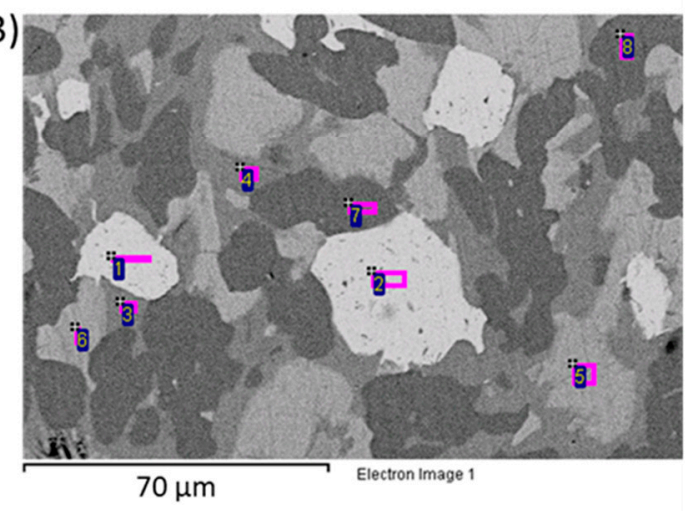

Figure 1. SEM micrographs of sample A performed in three different areas. EDXS measurements were collected in the squares.

\section{2. $X R D$}

The XRD analysis confirmed the crystalline phases predicted by EDXS (see Table 3), as reported in the Supplementary Material. The identified crystalline phases are those typically found in the scientific literature $[6,13,17,18]$. Sample A was analysed by $2 \mathrm{D}$ XRD in three areas of $300 \times 300 \mu \mathrm{m}^{2}$. The results confirm the presence of wüstite $(\mathrm{FeO})$, larnite $\left(\mathrm{Ca}_{2} \mathrm{SiO}_{4}\right)$, magnesioferrite $\left(\mathrm{Mg}\left(\mathrm{Fe}^{3+}\right)_{2} \mathrm{O}_{4}\right)$, iron oxide $\left(\mathrm{Fe}_{2} \mathrm{O}_{3}\right)$ and brownmillerite $\left(\mathrm{Ca}_{2}(\mathrm{AlFe})_{2} \mathrm{O}_{5}\right)$. Figure 2 shows the diffraction spectra of sample A. The 2D-XRD and SEM-EDXS analyses allow a certain identification of the crystalline phases, which were therefore used in the interpretation of micro-Raman results.

\subsection{Raman Spectroscopy}

The three areas of sample A analysed by SEM-EDXS and 2D XRD were tested by using $\mu$-Raman analysis (about 2 microns spots) and the spectra of each crystalline phase were identified [19].

The Raman spectra of the grain identified as larnite are reported in Figure 3a, and they are in good agreement with the Raman spectra reported in the literature [20]. The most significant Raman features of this phase are the bands at about 848,860 and $977 \mathrm{~cm}^{-1}$. Larnite can exist in different structures (namely, $\gamma$-phase and $\beta$-phase), and this Raman spectrum corresponds to the $\beta$-larnite phase. A large band of about $700 \mathrm{~cm}^{-1}$ is also present in the spectra. Since Fe was always detected in the larnite grains by EDXS (Table 3), the band can be attributed to iron oxide impurities. Indeed, brownmillerite and magnesioferrite, as well as magnetite, have strong bands at about $700 \mathrm{~cm}^{-1}$ [21]. 

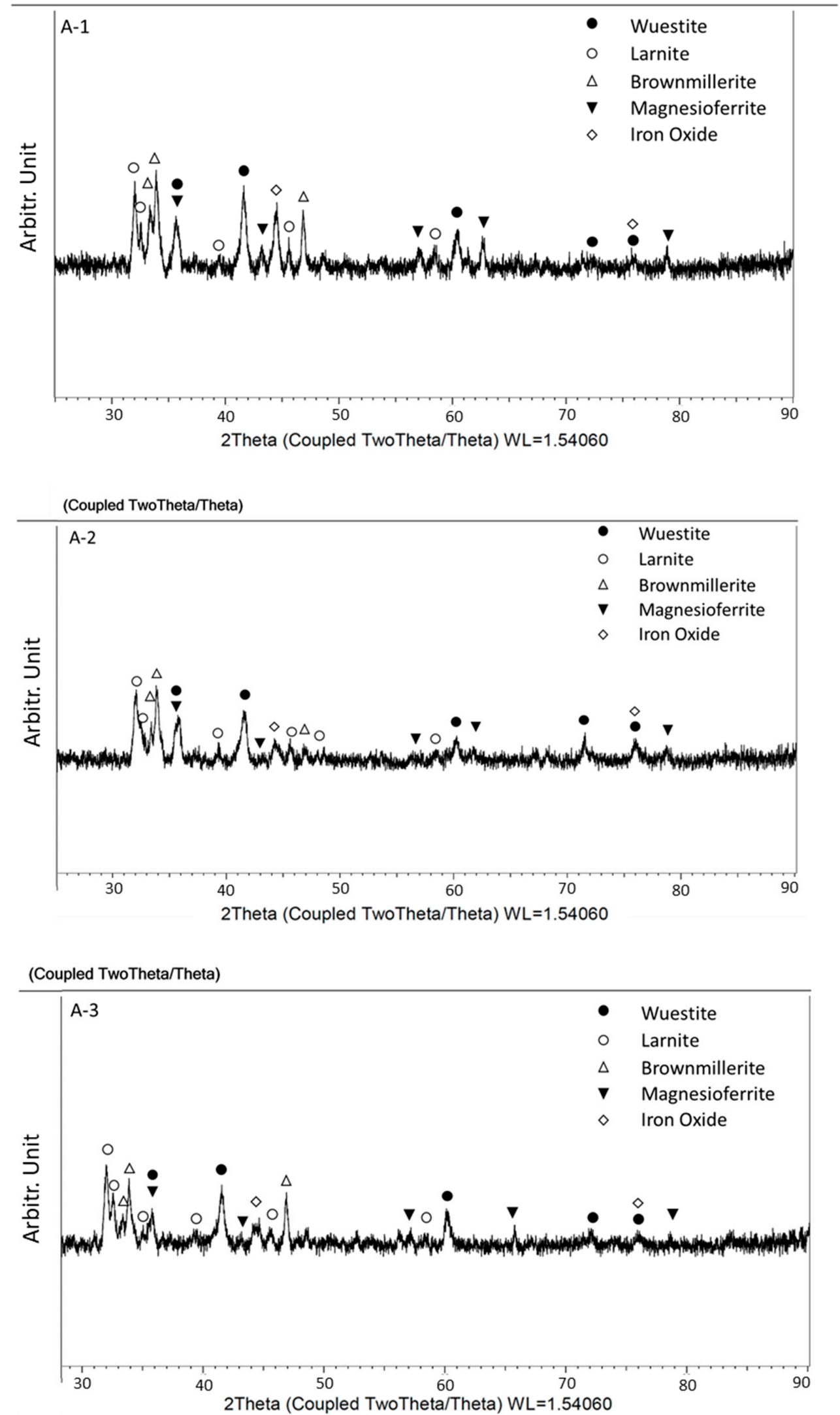

Figure 2. XRD patterns of three different $\left(300 \times 300 \mu \mathrm{m}^{2}\right)$ areas of sample A and the main crystalline identified phases. 
(a)

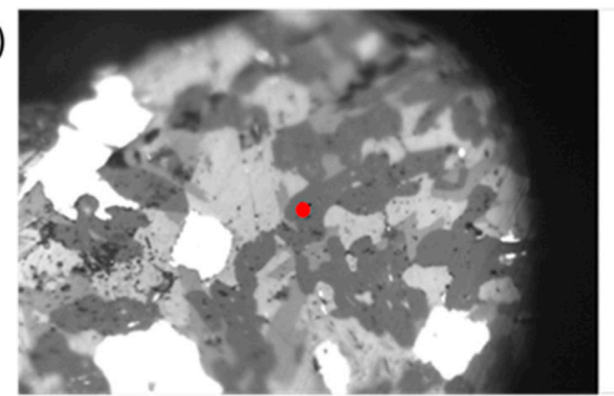

(b)

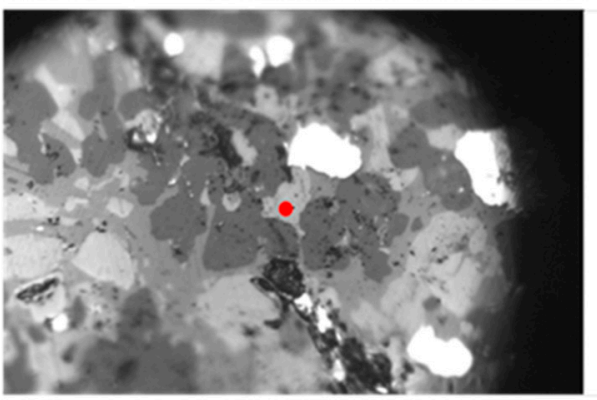

(c)

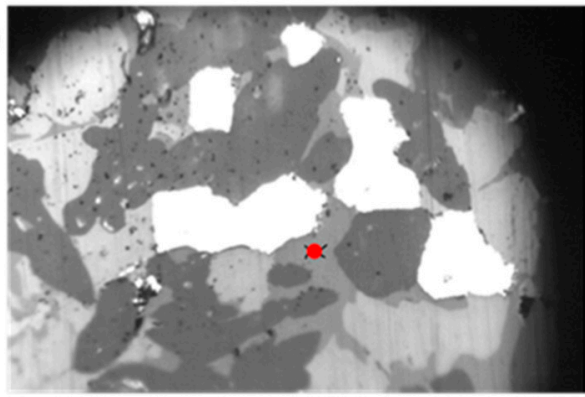

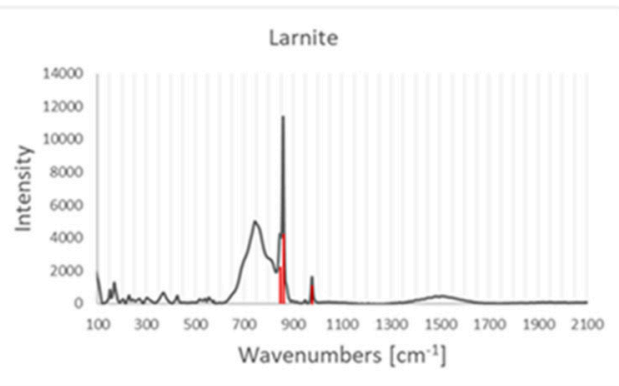
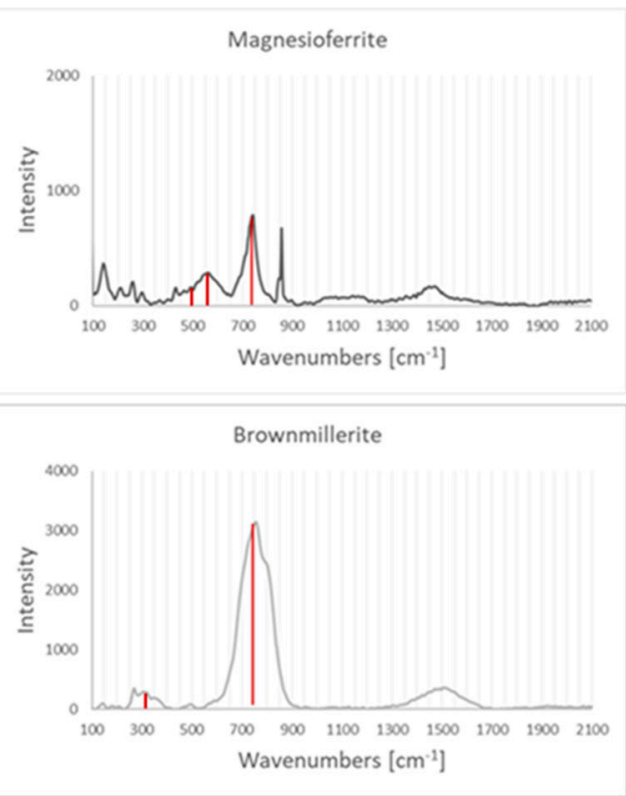

Figure 3. (a-c) $\mu$-Raman images (50× objective) and spectra of identified phases in the three areas of sample A.

In the second area (see Figure $3 b$ ), the presence of magnesioferrite phase is confirmed by the band at about $750 \mathrm{~cm}^{-1}$, due to the stretching $\mathrm{A}_{1 \mathrm{~g}}$ mode, and the $\mathrm{T}_{2 \mathrm{~g}}$ bands at about $500 \mathrm{~cm}^{-1}$ and $600 \mathrm{~cm}^{-1}$ [22]. In this spectrum, the main band of larnite at $860 \mathrm{~cm}^{-1}$ is also detected, as well as other minor signals that can be attributed to disordered iron oxides $[19,21,23,24]$.

In Figure 3c, the spectrum to that of the brownmillerite. The brownmillerite phase can present containing $\mathrm{Al}$ and $\mathrm{Fe}\left(\mathrm{Ca}_{2}\left(\mathrm{Al}, \mathrm{Fe}^{3+}\right)_{2} \mathrm{O}_{5}\right.$ and the $\mathrm{Al}$ content affects the position of the main Raman band, which shifts to the right (from about 710 to $750 \mathrm{~cm}^{-1}$ ) [25]. In our sample, brownmillerite is identified from the band at around $740 \mathrm{~cm}^{-1}$, suggesting a significant $\mathrm{Al}$ content [26-28]. A band at about $300 \mathrm{~cm}^{-1}$, characteristic of the brownmillerite phase, is also present [29]. Other bands are likely due to the presence of minor phases.

In samples B, C, D and E, XRD on powder makes it possible to identify further crystalline phases like gehlenite, wustite e magnesiochromite (see Figure 4). By $\mu$-Raman analysis, the spectra of each phase were identified to be in good agreement with the literature [30-33]. All the collected Raman spectra are reported in the Supplementary Material. 


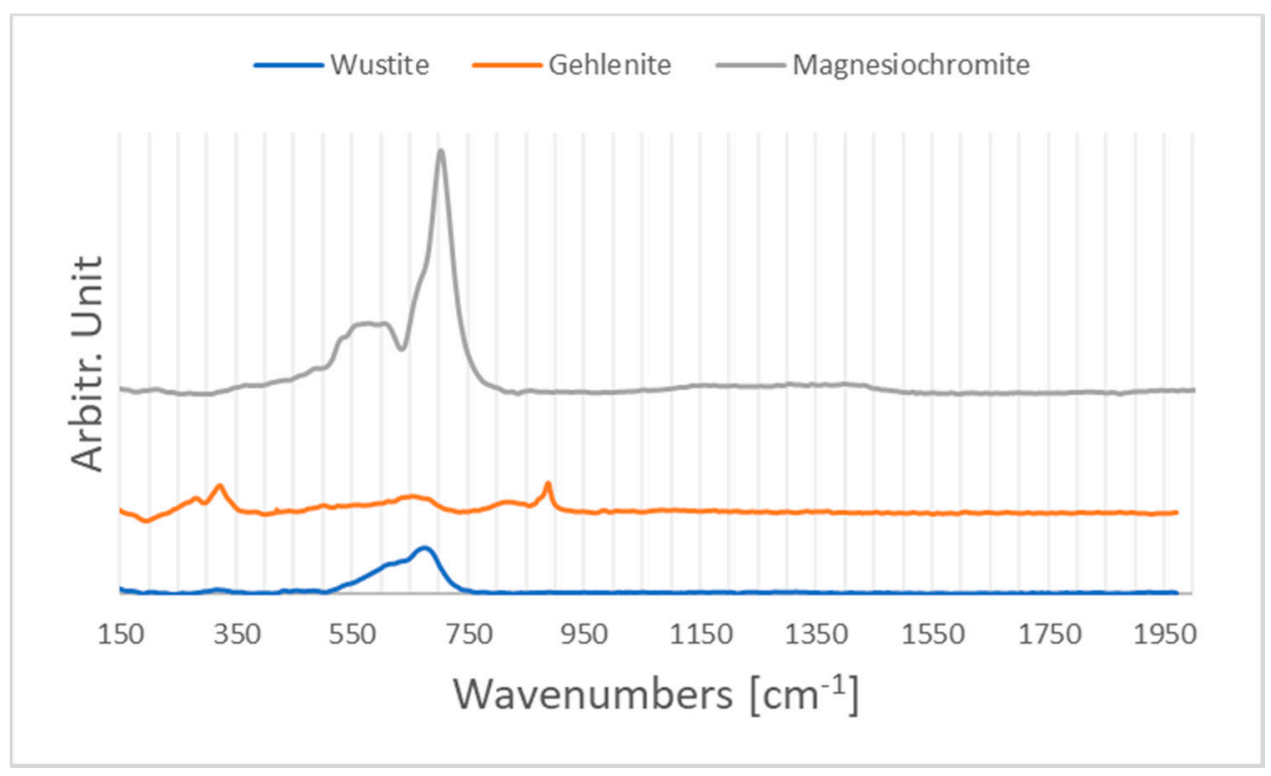

Figure 4. $\mu$-Raman and spectra example of magnesiochromite, wüstite and gehlenite identified phases in samples B, C, D and E. Time measurement $50 \mathrm{~s}$.

\section{Conclusions}

In this work, the crystalline phases, morphology and chemical composition of EAF black slag samples from five steel factories are studied. Samples characterised by well-developed crystalline phases were obtained. SEM-EDXS, 2D-XRD and $\mu$-Raman analysis were performed on the three different grain types, which were identified by SEM. The EDXS elemental composition made it possible to predict that the three types of grains mainly correspond to the brownmillerite, larnite and magnesioferrite phases identified by XRD. In the same area, $\mu$-Raman spectra were collected, and the results showed a good reproducibility in each grain and good agreement with the spectra of the phases reported in the literature.

No amorphous phases were identified, probably because the reference sample had been slowly cooled to allow the crystalline phases to grow. However, the identification of amorphous phases of EAF slag is a perspective for Raman analysis, and amorphous silicates have been widely studied [34-36]. A Raman database devoted to crystalline phases of EAF slag identification has been created to be used by portable Raman instruments, allowing phase characterisation of the slag directly during the steel production. Indeed, we believe that in the near future, Raman spectroscopy will be introduced into steelworks to carry out on-line slag analysis, which could be valuable for optimising processes during the steel production.

Supplementary Materials: The following are available online at http://www.mdpi.com/2076-3417/10/12/4115/s1, Figure S1. SEM micrographs of samples B, C, D and E. Numbered purple squares represent the position were EDXS measurements are collected, Table S1. SEM micrographs of samples B, C, D and E. Numbered purple squares represent the position were EDXS measurements are collected, Figure S2. XRD patterns of samples B, C, D and E, with the corresponding phase identification, Figure S3. Raman spectra of sample A, B, C, D and E. Time measurement $50 \mathrm{~s}$.

Author Contributions: Conceptualisation, A.R., L.B., I.V. and L.E.D.; methodology, A.R., L.B., L.E.D; software, A.R., I.V., G.C. and M.G.; investigation, A.R., I.V., G.C., M.G.; writing—original draft preparation, A.R.; writing-review and editing, L.B., I.V, A.C., M.V.B., G.C., M.G.; supervision, L.E.D.; project administration, L.E.D.; funding acquisition, L.E.D. Please refer to the CRediT taxonomy for the term explanation. All authors have read and agreed to the published version of the manuscript.

Funding: This research was funded by Regione Lombardia Cariplo Foundation 19037, 18-12-2018 on B.U.R.L. $n^{\circ} 52,27-12-2018$, grant $n^{\circ} 2018-1733$, project “Development of novel slag-based glass ceramic for plasma spray coating and 3D printing-3D SLAG", CUP E83D18000240009. 
Acknowledgments: The authors acknowledge RAMET consortium (Environmental Research for Metallurgy) for providing the samples.

Conflicts of Interest: The authors declare no conflict of interest. The funders had no role in the design of the study; in the collection, analyses, or interpretation of data; in the writing of the manuscript, or in the decision to publish the results.

\section{References}

1. Worldsteel Association. World Steel in Figures 2018; Worldsteel Association: Brussel, Belgium, 2018.

2. Yi, H.; Xu, G.; Cheng, H.; Wang, J.; Wan, Y.; Chen, H. An Overview of Utilization of Steel Slag. Procedia Environ. Sci. 2012, 16, 791-801. [CrossRef]

3. Yildirim, I.Z.; Prezzi, M. Chemical, Mineralogical, and Morphological Properties of Steel Slag. Adv. Civ. Eng. 2011, 2011, 1-13. [CrossRef]

4. Pellegrino, C.; Gaddo, V. Mechanical and durability characteristics of concrete containing EAF slag as aggregate. Cem. Concr. Compos. 2009, 31, 663-671. [CrossRef]

5. Barocci, A.; Luzzari, G.; Facchin, M. Procedure operative per la produzione di inerte artificiale in luogo di scoria nera. Metall. Ital. 2014, 5, 37-41.

6. Gelfi, M.; Cornacchia, G.; Conforti, S.; Roberti, R. Caratterizzazione di Scorie di Acciaieria e Studio del Rilascio di Cromo. In Proceedings of the Atti del 33 Convegno Nazionale AIM, Brescia, Italy, 10-12 November 2010.

7. Navarro, C.; Díaz, M.; Villa-García, M.Á.; Díaz, M. Physico-Chemical Characterization of Steel Slag. Study of its Behavior under Simulated Environmental Conditions. Environ. Sci. Technol. 2010, 44, 5383-5388. [CrossRef] [PubMed]

8. Gómez-Nubla, L.; Aramendia, J.; De Vallejuelo, S.F.-O.; Castro, K.; Madariaga, J.M. From Portable to SCA Raman devices to characterize harmful compounds contained in used black slag produced in Electric Arc Furnace of steel industry. J. Raman Spectrosc. 2013, 44, 1163-1171. [CrossRef]

9. Raman, C.V.; Krishnan, K.S. A New Type of Secondary Radiation. Nature 1928, 121, 501-502. [CrossRef]

10. Bumbrah, G.S.; Sharma, R.M. Raman spectroscopy-Basic principle, instrumentation and selected applications for the characterization of drugs of abuse. Egypt. J. Forensic Sci. 2016, 6, 209-215. [CrossRef]

11. Barone, G.; Bersani, D.; Crupi, V.; Longo, F.; Longobardo, U.; Lottici, P.P.; Aliatis, I.; Majolino, D.; Mazzoleni, P.; Raneri, S.; et al. A portable versus micro-Raman equipment comparison for gemmological purposes: The case of sapphires and their imitations. J. Raman Spectrosc. 2014, 45, 1309-1317. [CrossRef]

12. Fassina, P.; Brunella, F.; Lazzari, L.; Re, G.; Vergani, L.; Sciuccati, A. Fatigue Behavior Of Pipeline Steel Under Hydrogen Environment And Low Temperature. Procedia Eng. 2011, 10, 3345-3352. [CrossRef]

13. Gelfi, M.; Cornacchia, G.; Roberti, R. Investigations on leaching behavior of EAF steel slags. In Proceedings of the Euroslag 2010, Madrid, Spain, 19-22 October 2010; pp. 1-12.

14. Mombelli, A.D.; Mapelli, C.; Barella, S.; Gruttadauria, A.; Le Saoût, G.; García-Díaz, E. The efficiency of quartz addition on electric arc furnace (EAF) carbon steel slag stability. J. Hazard. Mater. 2014, 279, 586-596. [CrossRef] [PubMed]

15. Liu, L.; Hu long, M.; Bai guang, C.; Lü wei, X.; Xu zhou, Y.; Deng yu, Q. Effect of cooling rate on the crystallization behavior of perovskite in high titanium-bearing blast furnace slag. Int. J. Miner. Metall. Mater. 2014, 21, 1052-1061. [CrossRef]

16. Riboldi, A.; Cornacchia, G.; Gelfi, M.; Borgese, L.; Zacco, A.; Bontempi, E.; Boniardi, M.V.; Casaroli, A.; Depero, L.E. Grain Size Effect in Elution Test of Electric Arc Furnace Slag. Appl. Sci. 2020, 10, 477. [CrossRef]

17. Proctor, D.M.; Fehling, K.A.; Shay, E.C.; Wittenborn, J.L.; Green, J.J.; Avent, C.; Bigham, R.D.; Connolly, M.; Lee, B.; Shepker, T.O.; et al. Physical and Chemical Characteristics of Blast Furnace, Basic Oxygen Furnace, and Electric Arc Furnace Steel Industry Slags. Environ. Sci. Technol. 2000, 34, 1576-1582. [CrossRef]

18. Luxán, M.; Sotolongo, R.; Dorrego, F.; Herrero, E. Characteristics of the slags produced in the fusion of scrap steel by electric arc furnace. Cem. Concr. Res. 2000, 30, 517-519. [CrossRef]

19. Sokol, E.V.; Seryotkin, Y.V.; Kokh, S.N.; Vapnik, Y.; Nigmatulina, E.N.; Goryainov, S.V.; Belogub, E.V.; Sharygin, V.V. Flamite, $(\mathrm{Ca}, \mathrm{Na}, \mathrm{K}) 2(\mathrm{Si}, \mathrm{P}) \mathrm{O} 4$, a new mineral from ultrahightemperature combustion metamorphic rocks, Hatrurim Basin, Negev Desert, Israel. Miner. Mag. 2015, 79, 583-596. [CrossRef]

20. Remy, C.; Reynard, B.; Madon, M. Raman Spectroscopic Investigations of Dicalcium Silicate: Polymorphs and High-Temperature Phase Transformations. J. Am. Ceram. Soc. 2005, 80, 413-423. [CrossRef] 
21. RRUFF Database. Available online: https://rruff.info/ (accessed on 19 May 2020).

22. Wei, G.; Wei, L.; Wang, N.; Chen, Y.; Tian, Y.; Yan, S.; Mei, L.; Jiao, J. Reversible control of the magnetization of spinel ferrites based electrodes by lithium-ion migration. Sci. Rep. 2017, 7, 12554. [CrossRef]

23. D'Ippolito, V.; Andreozzi, G.B.; Bersani, D.; Lottici, P.P. Raman fingerprint of chromate, aluminate and ferrite spinels. J. Raman Spectrosc. 2015, 46, 1255-1264. [CrossRef]

24. Wang, Z.; Lazor, P.; Saxena, S.; O’NeilliD, H. High pressure Raman spectroscopy of ferrite $\mathrm{MgFe} 2 \mathrm{O} 4$. Mater. Res. Bull. 2002, 37, 1589-1602. [CrossRef]

25. Phan, T.-L.; Tran, N.; Kim, D.H.; Tho, P.; Huy, B.T.; Dang, T.N.; Yang, D.-S.; Lee, B. Electronic structure and magnetic properties of Al-doped Ca2 Fe2 O5 brownmillerite compounds. J. Am. Ceram. Soc. 2017, 101, 2181-2189. [CrossRef]

26. Lazic, B.; Krüger, H.; Kahlenberg, V.; Konzett, J.; Kaindl, R.; Krüger, B. Incommensurate structure of Ca2A12O5 at high temperatures-structure investigation and Raman spectroscopy. Acta Crystallogr. Sect. B Struct. Sci. 2008, 64, 417-425. [CrossRef]

27. Dhankhar, S.; Bhalerao, G.; Chandran, M.; Francis, B.; Tiwari, B.; Gupta, K.; Shukla, N.; Baskar, K.; Singh, S. Anomalous room temperature magnetoresistance in brownmillerite $\mathrm{Ca}_{2} \mathrm{Fe}_{2} \mathrm{O}_{5}$. RSC Adv. 2015, 5, 92549-92553. [CrossRef]

28. Piovano, A.; Ceretti, M.; Johnson, M.R.; Agostini, G.; Paulus, W.; Lamberti, C. Anisotropy in the Raman scattering of a $\mathrm{CaFeO} 2.5$ single crystal and its link with oxygen ordering in Brownmillerite frameworks. J. Physics Condens. Matter 2015, 27, 225403. [CrossRef] [PubMed]

29. Dhankhar, S.; Bhalerao, G.; Ganesamoorthy, S.; Baskar, K.; Singh, S. Growth and comparison of single crystals and polycrystalline brownmillerite $\mathrm{Ca}_{2} \mathrm{Fe}_{2} \mathrm{O}_{5}$. J. Cryst. Growth 2017, 468, 311-315. [CrossRef]

30. Sharma, S.K.; Simons, B.; Yoder, H.S. Raman study of anorthite, calcium Tschermak's pyroxene, and gehlenite in crystalline and glassy states. Am. Mineral. 1983, 68, 1113-1125.

31. Burshtein, Z.; Shimony, Y.; Morganau, S.; Henderson, D.; Mu, R.; Silberman, E. Symmetry lowering due to site-occupation disorder in vibrational spectra of gehlenite, Ca2(AlSi)AlO7. J. Phys. Chem. Solids 1993, 54, 1043-1049. [CrossRef]

32. Yong, W.; Botis, S.; Shieh, S.R.; Shi, W.; Withers, A. Pressure-induced phase transition study of magnesiochromite (MgCr2O4) by Raman spectroscopy and X-ray diffraction. Phys. Earth Planet. Inter. 2012, 196, 75-82. [CrossRef]

33. Strobel, R.E.; Pratsinis, S. Direct synthesis of maghemite, magnetite and wustite nanoparticles by flame spray pyrolysis. Adv. Powder Technol. 2009, 20, 190-194. [CrossRef]

34. Matson, D.W.; Sharma, S.K.; Philpotts, J.A. The structure of high-silica alkali-silicate glasses. A Raman spectroscopic investigation. J. Non-Cryst. Solids 1983, 58, 323-352. [CrossRef]

35. Park, Y.; Min, D.J. A Structural Study on the Foaming Behavior of $\mathrm{CaO}-\mathrm{SiO} 2-\mathrm{MO}(\mathrm{MO}=\mathrm{MgO}, \mathrm{FeO}$, or $\mathrm{Al} 2 \mathrm{O} 3)$ Ternary Slag System. Met. Mater. Trans. A 2017, 48, 3038-3046. [CrossRef]

36. Handke, M.; Mozgawa, W. Vibrational spectroscopy of the amorphous silicates. Vib. Spectrosc. 1993, 5, 75-84. [CrossRef]

(C) 2020 by the authors. Licensee MDPI, Basel, Switzerland. This article is an open access article distributed under the terms and conditions of the Creative Commons Attribution (CC BY) license (http://creativecommons.org/licenses/by/4.0/). 